During periods of flux, neurologic symptoms of hypoglycemia probably lag behind blood glucose levels. Herold ${ }^{4}$ found that the maximum change in neurologic response occurred 10 to 60 minutes after nadir glucose levels were reached. In addition, recurrent hypoglycemic episodes lead to a form of tolerance, with decreased production of insulin counter-regulatory hormones and reduced sympathetic response to hypoglycemia. ${ }^{5}$ This patient had attempted suicide at least once, recently, using insulin. And, based on his history of regular insulin use with poor, infrequent meals and recreational drug and alcohol abuse, he may also have had frequent episodes of hypoglycemia.

\section{Conclusion}

This patient's exceptional hypoglycemic tolerance may be explained by genetic predisposition, acquired tolerance and delayed onset of symptoms. Clinical findings may not always reflect serum glucose levels, and "occult" hypoglycemia may be more common than we think.

\section{References}

1. Mitrakou A, Ryan C, Veneman T, Modan M, Jenssen T, Kiss I, et al. Hierarchy of gylcemic thresholds for counter-regulatory hormone secretion, symptoms and cerebral dysfunction. Am J Physiol 1991;260:E67-E74.

2. Pramming S, Thorteinsson B, Theilgaard A, Pinner EM, Binder C. Cognitive function during hypoglycemia in type I diabetes mellitus. Br Med J 1986;292:647-50.

3. Holmes CS, Hayford JT, Gonzalez IL, Weydert JA. A survey of cognitive functioning at different glucose levels in diabetic persons. Diabetes Care 1983;6:180-5.

4. Herold KL, Polonsky KS, Cohen RM, Levy D, Douglas F. Variable deterioration in cortical function during insulin-dependent hypoglycemia. Diabetes 1985;34:677-85.

5. Heller SR, Cryer PE. Reduced neuroendocrine and symptomatic responses to subsequent hypoglycemia after 1 episode of hypoglycemia in non-diabetic humans. Diabetes 1991;40:223-6.

Correspondence to: Dr. G. Michael Allan, Base Hospital, CFB Esquimalt, PO Box 17000, Station Forces, Victoria BC V9A 7N2

\title{
Service Information
}

\section{Subscription and sales}

CJEM is supplied to CAEP's paid-up members as a perquisite of membership; others may subscribe yearly. Rates for 2000: Canada \$50, United States and elsewhere US\$50. Contact the CAEP office at $800463-1158$. Single copies of current year issues $\$ 15$; back issues $\$ 15$ (subject to availability). Canadian orders are subject to 7\% GST / 15\% HST (NS, NB, NF), as applicable. Payment should be made to the Canadian Association of Emergency Physicians (CAEP) in funds specified drawn on a Canadian or US bank, respectively. VISA and MasterCard are also accepted.

\section{Change of address}

We require 6-8 weeks' notice to ensure uninterrupted service. Please send your current mailing label, new address and the effective date of change to: CJEM@caep.ca or fax to 613 523-0190.

\section{Reprints}

Bulk reprints of CJEM articles are available in minimum quantities of 50. For information on orders, please contact the reprint coordinator, Janis Murrey, tel 800 663-7336 or 613 731-8610 x2110, fax 613 565-2382, murrej@cma.ca.

\section{Electronic availability}

CJEM is available online on the Internet (www.caep.ca).

\section{Permissions}

Copyright for all material is held by CJEM or its licencees. Unless otherwise indicated you may, without permission, for your noncommercial use, reproduce up to 10 copies of any specific item or portion thereof published in CJEM, provided that credit is given to the original source. You must have prior written permission for any reproduction, storage in a retrieval system or transmission, in any form or by any means. In the case of photocopying or other reprographic copying, please contact CJEM editorial office (c/o Dr. Grant Innes, Department of Emergency Medicine, St. Paul's Hospital, 1081 Burrard St., Vancouver BC V6Z 1Y6; tel 604 806-9050, fax 604 806-9057, ginnes@interchange.ubc.ca).

\section{Classified ads}

Contact Beverley Kirkpatrick, Manager, Journal Advertising, CJEM, 1867 Alta Vista Dr., Ottawa ON K1G 3Y6 (by courier: Ste. 500, 150 Isabella St., Ottawa ON K1S 1V7); tel 800 663-7336 or 613 731-8610 x2127, fax 613 565-7488, advertising@cma.ca. Please see the Classified Advertising section of the Journal for information on rates. 